\title{
ANALYSIS OF DOWN TIME AND RELIABILITY ESTIMATION IN A PROCESS INDUSTRY - A CASE STUDY
}

\author{
Sowmya Danalakshmi C. ${ }^{1}$, Mohankumar G. ${ }^{2}$ \\ ${ }^{1}$ Karpagam College of Engineering, Coimbatore, India. \\ ${ }^{2}$ Park College of Engineering and Technology., Coimbatore, India. \\ Email: 'csowmyadanalakshmi@rediffmail.com
}

\begin{abstract}
The growths of present day industries are forced towards the use of more and more complex systems. The production system consists of thousands of parts and components. The failure of one or more components may lead to affect the entire production system. So, with the increase in automation and usage of complex systems, evaluation of Reliability has recently been recognized for effective maintenance. Reliability has been evaluated mostly for electronic components since and presently we are going to calculate reliability for components in a process industry. For this purpose, the break down time is calculated from sugar Industry. The data is analyzed and reliability is calculated for each component by Weibull distribution in probability. Reliability is analyzed and criticality of each component is found by using FMEA (Failure Mode Effect Analysis) to suggest some of the preventive maintenance schedules. The study was carried in sugar mills limited in TamilNadu. The crushing capacity of the plant is 3500 Tones per day. The various processing sections of the factory are namely loading section, Mill section and boiling section. The preliminary discussions with the official's concerned reveal that the plant is often giving rise to problems due to break down of various components. Hence, it is decided to carry out failure analysis in this industry and to suggest measures to improve the availability of the components. The objective of this study is to estimate availability, reliability of the component system and also to perform the FMEA analysis to identify the critical components to prepare Preventive Maintenance (PM) schedules by the officials. The methodology followed to achieve this are Collection of the historical failure data of the production system, Calculating the down time and the availability of the equipment from the past data, Modeling the failure history using Weibull statistical distribution, Estimation of Reliability using Weibull parameters, Calculating criticality index of all the components using FMEA software and finally the preparation of maintenance schedule. It is possible to correlate the equipment reliability with maintenance requirements. To attain maximum productivity it is necessary that man minimize failure. This can be achieved by proper maintenance and timely replacement of some parts of machines or at times the whole equipment. An attempt has been made in this work to study the failure pattern and down time of the components. The critical components are also identified by carrying FMEAanalysis.
\end{abstract}

Keywords: Failure Mode EffectAnalysis, Weibull Distribution parameters, Criticality Index, Maintenance schedule \& Sugar Industry.

\section{INTRODUCTION}

The study was carried in sugar mills limited is situated Coimbatore district in Tamil Nadu. The crushing capacity of the plant is 3500 TCD (tones of cane crushed per day). The various processing sections of the factory are namely a) loading section b)mill section c)boiling section. The preliminary discussion with the officials concerned reveal that the plant is often giving rise to problems due to breakdown of various components. It is decided to carry out failure analysis in this industry, and to suggest measures to improve the availability of the components. The objective of the study is to estimate the availability, reliability of the components system and also to perform the FMEA analysis to identify the critical components to prepare PM (preventive maintenance) schedule by officials.

\section{METHODOLOGY}

1. The methodology followed to achieve this are

2. Collection of the historical failure data of the production system
3. Calculating the down time and the availability of the equipment from the past data

4. Modeling the failure history using Weibull statistical distribution

5. Estimation of Reliability using Weibull Parameters

6. Calculating criticality index of all the components using FMEA software

7. Finally the preparation of maintenance schedule.

\section{DATA COLLECTION}

Failure data of the plant are collected refers to average time of breakdown until the beyond repair. The mean time between failures is one of the useful terms in maintenance and reliability analysis. 
Table 1. Failure data for March month (from past data)

\begin{tabular}{|l|l|l|l|l|}
\hline Date & From & To & $\begin{array}{l}\text { Total } \\
\text { Hrs }\end{array}$ & Reason \\
\hline 02.03 .05 & 7.20 & 7.45 & 0.25 & $\begin{array}{l}\text { Reduce } \\
\text { Juice level } \\
\text { in the } \\
\text { evaporator }\end{array}$ \\
\hline & 8.45 & 9.20 & 0.35 & holidav \\
\hline 03.03 .05 & - & - & - & holidav \\
\hline 04.03 .05 & - & - & - & $\begin{array}{l}\text { Water } \\
\text { scarcitv }\end{array}$ \\
\hline 05.03 .05 & 8.30 & 8.55 & 0.25 & $\begin{array}{l}\text { Kicker } \\
\text { iammina }\end{array}$ \\
\cline { 2 - 5 } & 9.25 & 9.40 & 0.15 & \multicolumn{3}{|l}{} \\
\hline
\end{tabular}

\section{MEAN TIME BETWEEN FAILURES (MTBF)}

The mean time between failures refers to average time of breakdown until the device beyond repair. The mean time between failures is one of the useful terms in maintenance and reliability analysis.

\section{MTBF = Operating Time/Number of failures}

\section{AVAILABILITY}

It is possible to define three types of availability depending on the time elements we take in to consideration. These are inherent availability, which means that the probability that a system or equipment shall operate satisfactorily when used under stated conditions in an ideal support environment without consideration for any scheduled or preventive maintenance at any given time. Achieve availability means, in the definition of inherent availiabilty we considered MTBF which does not take in to account the downtime caused by maintenance.

If this is also taken into account, we get the achieved availability, which is defined to the probability that a system or equipment shall operate satisfactorily when used under stated conditions in an ideal support environment at any given time. In any real time operation, we can't reduce administrative downtime and supply downtime to zero. A certain amount of delay will always be caused by time elements such as these, and if they are taken in to account it.

Operational availability of the system be the probability that a system or equipment shall operate satisfactorily and in an actual supply environment at any given time.

$$
\mathrm{A}_{0}=\mathrm{MTBF} /(\mathrm{MTBF}+\mathrm{MDT})
$$

Where MTBF mean time between failures, MDT mean down time.

\section{ESTIMATION OF OPERATIONAL AVAILABILTY}

\section{Downtime of components}

Downtime is the non-productive time of the machine. Downtime of the components are calculated and tabulated with the help of the data collected table 2 shows the downtime of the various components from March 04 to May 04 . For example, The downtime of the CANECARRIER during March 04 is observed to be 6.45 hrs: min, which is the sum of the breakdown hours on various occasions during the month of March 04. Similarly for all other components, for various periods, the want of cane time are calculated and tabulated. Table 3 presents the data with respect to number of failures for each component month wise.

Table 2. Down Time of Components (Past Data)

\begin{tabular}{|l|l|l|ll|l|}
\hline S.No & Component & March & April & May & $\begin{array}{l}\text { Total } \\
\text { Hrs }\end{array}$ \\
\hline 1 & $\begin{array}{l}\text { Cane } \\
\text { Carrier }\end{array}$ & 6.20 & 5.15 & 1.10 & 12.45 \\
\hline 2 & Mills & 10.30 & 6.20 & 1.40 & 17.90 \\
\hline 3 & $\begin{array}{l}\text { Bagasse } \\
\text { Carrier }\end{array}$ & 3.40 & 4.40 & 2.25 & 10.05 \\
\hline 4 & Evaporator & 1.40 & 0.20 & 1.50 & 3.10 \\
\hline 5 & $\begin{array}{l}\text { Low Pr. } \\
\text { Boiler }\end{array}$ & - & 2.55 & 0.50 & 3.05 \\
\hline 6 & $\begin{array}{l}\text { Raw Juice } \\
\text { pump }\end{array}$ & 9.00 & 2.40 & 1.50 & 12.90 \\
\hline
\end{tabular}

Table 3. No. of Failures of all components

\begin{tabular}{|l|l|l|ll|l|}
\hline S.No & Component & March & April & May & $\begin{array}{l}\text { No. } \\
\text { of } \\
\text { Fails }\end{array}$ \\
\hline 1 & $\begin{array}{l}\text { Cane } \\
\text { Carrier }\end{array}$ & 3 & 4 & 2 & 9 \\
\hline 2 & Mills & 5 & 5 & 2 & 12 \\
\hline 3 & $\begin{array}{l}\text { Bagasse } \\
\text { Carrier }\end{array}$ & 2 & 4 & 2 & 8 \\
\hline 4 & Evaporator & 4 & 2 & 3 & 9 \\
\hline 5 & $\begin{array}{l}\text { Low Pr. } \\
\text { Boiler }\end{array}$ & - & 3 & 2 & 5 \\
\hline 6 & $\begin{array}{l}\text { Raw Juice } \\
\text { pump }\end{array}$ & 4 & 5 & 2 & 11 \\
\hline
\end{tabular}


Table 4. General Down Time of the industry

\begin{tabular}{|l|l|l|l|l|}
\hline Month & $\begin{array}{l}\text { Gen. } \\
\text { Cleaning }\end{array}$ & $\begin{array}{l}\text { Cane } \\
\text { Shortage }\end{array}$ & Holiday & Total \\
\hline March & 19.30 & 65.05 & 71.00 & 155.35 \\
\hline April & 15.35 & 3.05 & 45.00 & 65.45 \\
\hline May & 55.25 & 53.35 & 110.00 & 175.35 \\
\hline
\end{tabular}

\section{RELIABILITY ESTIMATION}

\section{A. Definition of reliability}

Reliability, which is a measure of quality, is an essential element at each stage of the equipment manufacturing procedure through design and production to final delivery to the user. Reliability, it is simplest form, means the probability that a failure may not occur in a given time interval. A more rigorous definition of reliability is a follows "reliability of a unit (or product) is the probability that the unit performs its intended operating conditions or environment". Reliability characteristics, such as probability of survival, mean time to failure, availability, mean down time and frequency of failures are some of the measures of system effectiveness. Apart from the above factors, reliability does change due to other factors like quality, workmanship, manufacturing process, material, storage, handling, engineering changes, and deviations in production, inspection and test.

\section{B. Application of weibull distribution}

In 1951, weibull suggested a simple empirical expression, which represents a great varies of actual data. The weibull cumulative distribution function is given by, $(\mathrm{t}-N / \alpha)^{\beta}$

$F(t)=1-e, \quad t>\lambda, \beta>0$

$$
=0 \text {, otherwise }
$$

Where,

a-Scale parameter

$\lambda$-Location factor

$\beta$-Shape factor

The various functions are given as

$$
\left.R(t)=\exp [-(t-\gamma) / \alpha)^{\beta}\right]
$$

$\lambda(t)=$ Failure rate $=\beta / \alpha((t-\gamma) / \alpha) \beta-1$

\section{MTBF of components}

Mean time between failures is referred to as the average time to satisfactory operation of the system. This term is useful to carryout the maintenance and reliability analysis
MTBF = $($ Total Available Time - Non-operating time $) /$ No. of failures

\section{For Example:}

Component name $=$ Cane carrier

Total available time $=(31+30+31) \times 24 \mathrm{hrs}=2208 \mathrm{hrs}$.

Non operating time $=$ Total break down time of cane carrier $=12.45 \mathrm{hrs}$

Number of failures $=9$ (from Table 3 )

MTBF $=(2208-12.45) / 9=243.95 \mathrm{hrs}$

Thus, Table 5 shows the MTBF of all the components

Table 5. MTBF of various components considered

\begin{tabular}{|l|l|l|}
\hline S. No. & Component Name & $\begin{array}{l}\text { MTBF } \\
\text { Value(hrs) }\end{array}$ \\
\hline 1 & Cane carrier & 243.95 \\
\hline 2 & Mills & 182.51 \\
\hline 3 & Bagasse Carrier & 274.74 \\
\hline 4 & Evaporator & 244.99 \\
\hline 5 & Low Pressure Boiler & 440.99 \\
\hline 6 & Raw Juice pump & 199.55 \\
\hline
\end{tabular}

VIII. MEAN DOWN TIME

The statistical mean of downtime d1,d2,d3, ". Including supply time and administrative downtime is called mean downtime. This mean downtime is concentrated on breakdown time, maintenance time and non-availability of components. Table 6 shows the mean downtime of various components.

\section{For example:}

$\begin{array}{ll}\text { Month } & =\text { March } \\ \text { Component } & =\text { Cane carrier }\end{array}$

Downtime due to break down(BDT) $=6.20 \mathrm{hrs}$ (from Table B)

General down time $(G D T)=155.35 \mathrm{hrs}$ (from Table D)

Total down time $($ TDT $) \quad=6.20+155.35=161.55 \mathrm{hrs}$

$$
\begin{array}{ll}
\text { Month } & =\text { April } \\
\text { Component } & =\text { Cane carrier }
\end{array}
$$

Downtime due to break down $(B D T)=5.15 \mathrm{hrs}$ (from Table B)

General down time $(\mathrm{GDT})=65.45 \mathrm{hrs}$ (from Table D)

Total down time $($ TDT $) \quad=5.15+65.45=70.60 \mathrm{hrs}$
Month
$=$ May
Component
$=$ Cane carrier 
Downtime due to break down $(\mathrm{BDT})=1.10 \mathrm{hrs}$ (from Table B)

General down time $($ GDT $)=175.35 \mathrm{hrs}$ (from Table D)

Total down time $($ TDT $)=1.10+175.35=176.45 \mathrm{hrs}$

Mean down time(TDT Mar + TDT April + TDT May) $=$ $(161.55+70.60+176.45)=136.20 \mathrm{hrs}$

Mean Down Time of Cane carrier $=136.20 \mathrm{hrs}$

Table 6. Mean Down Time of Components

\begin{tabular}{|l|l|l|l|l|l|}
\hline S.No & Component & \multicolumn{3}{|c|}{ Mean Down Time(hrs) } & \multicolumn{1}{l}{$\begin{array}{l}\text { Total } \\
\text { MDT }\end{array}$} \\
\cline { 3 - 6 } & & March & April & May & Cane \\
& Carrier & 161.55 & 70.60 & 176.45 & 136.20 \\
\hline 2 & Mills & 165.65 & 71.65 & 176.75 & 138.02 \\
\hline 3 & $\begin{array}{l}\text { Bagasse } \\
\text { Carrier }\end{array}$ & 158.75 & 69.85 & 177.60 & 135.40 \\
\hline 4 & Evaporator & 156.75 & 65.65 & 176.85 & 133.08 \\
\hline 5 & $\begin{array}{l}\text { Low Pr. } \\
\text { Boiler }\end{array}$ & 155.35 & 68 & 175.85 & 133.07 \\
\hline 6 & $\begin{array}{l}\text { Raw Juice } \\
\text { pump }\end{array}$ & 134.35 & 67.85 & 176.85 & 136.35 \\
\hline
\end{tabular}

\section{AVAILABILITY OF COMPONENTS}

It is possible to define three types of availability of equipment hours in actual environments operational availability is defined as to be the probability that a system of equipment shall operate satisfactorily when used under stated condition in an actual environment at any given time.

\section{$A_{0}=\{M T B F /(M T B F+M D T)\} \times 100$}

\section{For Example,}

Component name $=$ Cane carrier

MTBF $=243.95 \mathrm{hrs}$

MDT $=136.20 \mathrm{hrs}$

Availability $=243.95 /(243.95+136.20)=0.6134 \times 100=$ $64.17 \%$. Thus the availability of all the components were calculated and given in Table 7 .
Table 7. Availability of components

\begin{tabular}{|l|l|l|l|l|}
\hline $\begin{array}{l}\text { S.N } \\
\mathbf{0 .}\end{array}$ & $\begin{array}{l}\text { Compone } \\
\text { nt }\end{array}$ & MTBF & MDT & $\begin{array}{l}\text { Availa } \\
\text { bility } \\
(\%)\end{array}$ \\
\hline 1 & $\begin{array}{l}\text { Cane } \\
\text { Carrier }\end{array}$ & 243.95 & 136.20 & 64.17 \\
\hline 2 & Mills & 182.51 & 138.02 & 56.94 \\
\hline 3 & $\begin{array}{l}\text { Bagasse } \\
\text { Carrier }\end{array}$ & 274.74 & 135.40 & 66.99 \\
\hline 4 & Evaporator & 244.99 & 133.08 & 64.80 \\
\hline 5 & $\begin{array}{l}\text { Low Pr. } \\
\text { Boiler }\end{array}$ & 440.99 & 133.07 & 76.82 \\
\hline 6 & $\begin{array}{l}\text { Raw Juice } \\
\text { pump }\end{array}$ & 199.55 & 136.35 & 59.41 \\
\hline
\end{tabular}

Locating constant defining the starting point or origin of the distribution can be thought as a guarantee period in which no failure can occur or it can be though of as the minimum life. When dealing with failure rate, the Weibull shape parameter $\beta$, is of special importance as it describes the mode of failure. If

$\beta$ i 1- It indicates that failure rate is decreasing function of time and is characterized as an early failure phase.

If $\beta=1-$ It means the failure rate is constant overtime, as is the case for exponential distribution.

If $\beta 1 / 21$ - It means the failure rate is increasing with time and can be characterized as the wear out phase.

\section{$X$. FAILURE TIME DISTRIBUTION : CALCULATION PROCEDURES}

The following procedure is adopted to calculate the required parameters.

Class Interval :

$\mathrm{I}=\left(\mathrm{T}_{\max }-\mathrm{T}_{\min }\right) /(1+3.3 \log \mathrm{N})$

Where, $T_{\text {max }}$ - Maximum time between failures \& $T_{\text {min }}$ Minimum time between failures

$\mathrm{N}$ - Total number of failures in the test time

\section{PERCENTAGE OF FAILURE:}

$\%$ failed $=$ (No. of failures in the time interval $/$ Total no. of failures)

\section{CUMMULATIVE \% OF FAILURE:}

$F(t)=\varepsilon^{n} f_{i}$

$1=1$

$\mathrm{n}$-corresponding time interval sequence number 
RELIABILITY:

$\left.R(t)=\exp [-(t-\gamma) / \alpha)^{\beta}\right]$

\section{RELIABILITY OF COMPONENTS}

\section{For example,}

Component Name: Cane carrier

From Weibull graph $\alpha=1400 \& \beta=1.6$

$(\mu / \alpha)=0.888$

Therefore, $\mu=0.888 \times 1400=1243.20$

$\mathrm{t}=(\mu+\gamma)=1243.20+0=1243.20 \mathrm{hrs}$.

$\left.\mathrm{R}(\mathrm{t})=\exp [-(\mathrm{t}-\mathrm{\gamma}) / \mathrm{\alpha})^{\beta}\right] \times 100$

$\left.=\exp [-(1243.20-0) / 1400)^{1.6}\right] \times 100$

$R(t)=43.74 \%$

Thus, the Reliability is calculated for all the components under consideration and tabulated in table 8. From the calculation it is found that the Reliability of Raw juice pump is very less.

Table 8. Reliability of components

\begin{tabular}{|l|l|l|l|r|}
\hline S.No & Componenet & $\alpha$ & $\beta$ & $\mathrm{R}(\mathrm{t})$ \\
\hline 1 & Cane Carrier & 1400 & 1.6 & 43.74 \\
\hline 2 & Mills & 1300 & 1.5 & 43.31 \\
\hline 3 & $\begin{array}{l}\text { Bagasse } \\
\text { Carrier }\end{array}$ & 1370 & 2.4 & 47.15 \\
\hline 4 & Evaporator & 1250 & 1.2 & 42.02 \\
\hline 5 & Low Pr.Boiler & 1500 & 2.5 & 47.57 \\
\hline 6 & $\begin{array}{l}\text { Raw Juice } \\
\text { Pump }\end{array}$ & 900 & 0.6 & 39.42 \\
\hline
\end{tabular}

\section{FMEA (FAILURE MODE AND EFFECT ANALYSIS) INTRODUCTION}

FMEA is a logical structured analysis of a system, subsystem, device or process. It is one of the most commonly used reliability and system safety analysis techniques. FMEA is used to identify possible failure modes, their causes and the effects of these failures. Proper identification of failure may lead to solutions that increase the overall reliability and safety of a product FMEA analysis is a powerful design and reliability tool that examines the potential failure modes with in a system in order to determine its effect on the system performance.

\section{FMEA ANALYSIS AND PROCESS} an FMEA,

The following logical steps should be followed when Identify the product or system components.
1. Listall possible failure modes of each component.

2. Set down the effects that each mode of failure would have on the over all function of product system.

3. List all the possible causes of each failure mode.

4. Assess numerically the failure modes on a scale from 1 to 10.

5. Experience and reliability data from company is given as input to determine the values, on a scale 1-10 for severity (S), occurence(O), detection (D).

\section{SEVERITY(S)}

Severity is the assessment of the seriousness of the effect of potential failure of the system, subsystem or component severity is applicable only to effect of failure mode severity is rated by ranking by ranking by which 1 is for no effect and 10 for the most severe (serious) effect.

\section{OCCURRENCE (0)}

Occurrence is the probability that one of the specific cause / mechanism of failure will occur. The likelihood of occurrence is assessed as 1 for least chance of occurrence and 10 for highest chance of occurrence.

\section{DETECTION (D)}

It is the relative measure of difficulty of detecting the failure before the product or service is used by customer. If the design control certainly detects cause/mechanism of failure then it is ranked or it is difficult or detect then it is ranked. The details of $T_{\max } \& T_{\min }$ from past of the industry is given the Table 9. Thus

when these inputs are given, the results generated from the software are tabulated in table 10.The criticality index for each components is generated and ranked according to the critical failure modes. This indicates the relative priority of each failure mode and to concentrate on preventive activity of critical components.

Table 9. $T_{\max } \& T_{\min }$ (From Past Data)

\begin{tabular}{|c|ll|l|}
\hline S.No & Component & $\mathrm{T}_{\max }(\mathrm{hrs})$ & $\mathrm{T}_{\min }(\mathrm{hrs})$ \\
\hline 1. & $\begin{array}{l}\text { Cane } \\
\text { Carrier }\end{array}$ & 601.45 & 39.15 \\
\hline 2. & Mills & 400.20 & 1.50 \\
\hline 3. & $\begin{array}{l}\text { Bagasse } \\
\text { Carrier }\end{array}$ & 568.45 & 32.00 \\
\hline 4. & Evaporator & 776.15 & 1.15 \\
\hline 5. & $\begin{array}{l}\text { Low Pr. } 785.75 \\
\text { Boiler }\end{array}$ & 267.15 \\
\hline 6. & $\begin{array}{l}\text { Raw Juice } \\
\text { pump }\end{array}$ & 1.05 .00 \\
\hline
\end{tabular}


Table 10. Criticality Index

\begin{tabular}{|c|c|c|c|c|c|c|c|c|}
\hline S.No. & Component & $\begin{array}{l}\text { Mode of } \\
\text { Failure }\end{array}$ & $\begin{array}{l}\text { Failure } \\
\text { effects }\end{array}$ & Causes & Severity & Occurrence & Detection & $\begin{array}{l}\text { Criticality } \\
\text { index }\end{array}$ \\
\hline 1. & $\begin{array}{l}\text { Cane } \\
\text { Carrier }\end{array}$ & $\begin{array}{l}\text { Plate of } \\
\text { carrier }\end{array}$ & $\begin{array}{l}\text { Drive is } \\
\text { affected }\end{array}$ & $\begin{array}{l}\text { Plate } \\
\text { corrosion }\end{array}$ & 3 & 4 & 1 & 12 \\
\hline 2. & Mills & $\begin{array}{l}\text { Conveyor } \\
\text { Belt }\end{array}$ & $\begin{array}{l}\text { Bagasse } \\
\text { discharge } \\
\text { is affected }\end{array}$ & $\begin{array}{l}\text { Worn out } \\
\text { of belt }\end{array}$ & 4 & 5 & 3 & 60 \\
\hline 3. & $\begin{array}{l}\text { Bagas se } \\
\text { Carrier }\end{array}$ & $\begin{array}{l}\text { Drive } \\
\text { chain }\end{array}$ & $\begin{array}{l}\text { Bagas se } \\
\text { discharge } \\
\text { is affected }\end{array}$ & $\begin{array}{l}\text { Bagasse } \\
\text { Jamming }\end{array}$ & 2 & 6 & 4 & 48 \\
\hline 4. & Evaporator & $\begin{array}{l}\text { Sulphur } \\
\text { oxide } \\
\text { gasline }\end{array}$ & $\begin{array}{l}\text { Gas } \\
\text { leakage }\end{array}$ & Corrosion & 5 & 4 & 5 & 100 \\
\hline 5. & $\begin{array}{l}\text { Low } \quad \mathrm{Pr} . \\
\text { Boiler }\end{array}$ & Pr. Drop & $\begin{array}{l}\text { Production } \\
\text { of steam is } \\
\text { affected }\end{array}$ & $\begin{array}{l}\text { Scarcity of } \\
\text { wateer }\end{array}$ & 6 & 6 & 4 & 144 \\
\hline 6. & $\begin{array}{l}\text { Raw Juice } \\
\text { pump }\end{array}$ & Pipe line & $\begin{array}{l}\text { Juice } \\
\text { leakage }\end{array}$ & Corrosion & 1 & 5 & 6 & 30 \\
\hline
\end{tabular}

\section{CONCLUSION}

Thus, the criticality index of all the components were calculated and analyzed. So that the components can be effectively used after rectifying the failures according to the severity. Availability of data regarding the equipment Reliability is of considerable benefit to industry in many situations. Knowledge of wear out characteristics of the system components leads to the development of appropriate provision for spare parts and stand by equipments. It is possible to correlate equipment maintenance requirements. Machines made by man at any time succumb to fail. To attain maximum productivity it is necessary that man minimize failure. This can be achieved by proper maintenance and timely replacements of some parts of machines or at times the whole equipment. The timely replacement improves the machine Reliability as well as Availability and made it useful for achieving high productivity. An attempt had been made in this thesis to study the failure pattern and down time of the components used in a particular industry under consideration. The critical components have also been identified by carrying out FMEA analysis. It will be economical if the failures of these critical components are minimized by proper preventive maintenance measures.

\section{REFERENCES}

[1] Carter, C.R, 2000, Ethical issues in international buyer-supplier relationships - Adyadic examination, in: Journal of Operations Management, Vol. 18, No. 2, pp. 191-208.
[2] Cooper, R.W, Frank, G.L Kemp, R.A, 2000, "A multinational comparison of key ethical issues, helps and challenges in the purchasing and supply management profession - The key implications for business and the professions, in": Journal of Business Ethics, Vol. 23, No. 1, pp. 83-100

[3] Carbett, Lawrence. M \& Rostrick ,2000, Quality Performance and Organisation Culture : A New Zealand Study", International Journal of Quality and Reliability Management, Vol.17:1.

[4] Debadyuti Das, 2001, "Total productive maintenance (TPM):A comprehensive tool for achieving excellence in the operations system $-A$ case study", Industrial Engineering Journal, Vol. xxx No.20, October, pp.15.

[5] Garvalia. N. N, 2003, "Productivity Improvement through the 5S's - A case study", Industrial Engineering Journal, Vol. XXXII No.22, pp. 4-6.

[6] Govil. A. K,1983, Reliability Engineering, TATA McGraw Hill Company Ltd,. NewDelhi

[7] Harland, C.M. Lamming, R.C, Cousins, P.D. 1999, Developing the concept of supply strategy, in: International Journal of Operations \& Production Management, Vol. 19, No. 7, pp. 650-673.

[8] Laforge. R. L., C.W. Craighead,2000, "Computerbased scheduling in Manufacturing firms : some indicators of successful practice", Production and Inventory Management Journal 41 (1) pp. 3-24. 
[9] Lewis. W.W, 1987, "Introduction to reliability Engineering", john Willey \& Sons, Newyork.

[10] Malik. M. A. K, 1979, "A Note on the Physical Meaning of the Weibull Distribution", IEEE transactions on Reliability, ol.24,No.2,pp.95

[11] Sheth, J.N Sharma, A, 1997, Supplier relationships, in: Industrial Marketing Management, Vol. 26, No. 2, pp. 91-100.

[12] Sinha. S.K, 1980, "Life Testing and Reliability Estimation" Weily Eastern Limited, India.
[13] Tensine. R.J, 2000, Principles of Materials and Inventory Management, Prentice Hall, $4^{\text {th }}$ Edition.

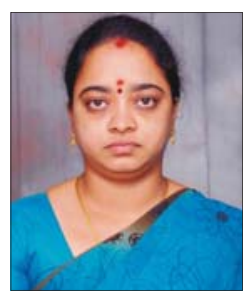

Sowmya is a lecturer at the Karpagam college of Engineering, Coimbatore. Her areas of research include Industrial Engineering, Production Management \& Welding. She has published 15 research papers in Journals and Conferences. 